Note

\section{In Vitro Inactivation of Rabbit Reticulocyte 60S Ribosomal Subunits by Colicin E3}

\author{
Haruo Suzuki, Yoichi ManabE* \\ and Takahisa OHTA* \\ Department of Biophysical Chemistry, Kitasato \\ University, School of Medicine, \\ Sagamihara, Kanagawa \\ 228, Japan \\ * Department of Agricultural Chemistry, Faculty \\ of Agriculture, University of \\ Tokyo, Bunkyo-ku, Tokyo \\ 113, Japan
}

Received October 7, 1985

We have shown that colicin E3 inhibits rabbit globin synthesis in a rabbit reticulocyte cell-free system and suggested that the inhibition is due to the inactivation of either the $60 \mathrm{~S}$ ribosome subunits or some site(s) of $40 \mathrm{~S}$ subunits for the formation of $80 \mathrm{~S}$ initiation complexes. ${ }^{1)}$ The aim of this work is to find out which of these possibilities is correct.

Rabbit reticulocytes lysate was prepared as described ${ }^{2)}$ and the ribosome concentration of the lysate was $24.5 A_{260}$ units $/ \mathrm{ml}$. Highly purified colicin E3 was prepared by the method described ${ }^{3}$. L-[Ala-2,3- $\left.{ }^{3} \mathrm{H}\right]-\mathrm{Phe}(24.0 \mathrm{Ci} / \mathrm{mmol})$ was from New England Nuclear Corp. Poly(U) was from P-L Biochemicals.

The $\mathrm{pH} 5$ enzyme was prepared from rabbit liver by the method of Falvey and Staehelin ${ }^{4}$ with minor modifications. The liver $(15 \mathrm{~g})$ was homogenized in $40 \mathrm{ml}$ of ice-cold buffer $(0.3 \mathrm{M}$ sucrose, $10 \mathrm{~mm}$ Tris- $\mathrm{HCl}(\mathrm{pH}$ 7.4), $1 \mathrm{~mm}$ mercaptoethanol, $5 \mathrm{~mm}$ magnesium acetate). The homogenate was centrifuged at $12,000 \mathrm{rpm}$ for $20 \mathrm{~min}$ in a Hitachi rotor RPR20. The supernatant was centrifuged at $60,000 \mathrm{rpm}$ for $1.5 \mathrm{hr}$ in a Hitachi rotor RP65. Approximately two-thirds of the supernatant was then diluted with two volumes of ice-cold distilled water containing $1 \mathrm{~mm}$ mercaptoethanol and the $\mathrm{pH}$ was adjusted to 5.1 with $1 \mathrm{~m}$ acetic acid. The precipitates were collected by centrifugation and dissolved in ice-cold buffer $(20 \mathrm{~mm}$ Tris- $\mathrm{HCl}$ (pH 7.4), $1 \mathrm{~mm}$ mercaptoethanol, $5 \mathrm{~mm}$ magnesium acetate). Undissolved material was removed by centrifugation and the supernatant was kept in small vials at $-70^{\circ} \mathrm{C}$.

To prepare control and colicin E3-treated ribosomal subunits, $0.55-\mathrm{ml}$ portions of reticulocyte lysate were preincubated with various concentrations of colicin E3 in $1 \mathrm{ml}$ of a mixture containing $30 \mathrm{~mm}$ Tris- $\mathrm{HCl}(\mathrm{pH} 7.4)$, $70 \mathrm{~mm} \mathrm{KCl}, 40 \mu \mathrm{M}$ each of 19 L-amino acids minus methionine, $1 \mathrm{~mm}$ mercaptoethanol, $50 \mu \mathrm{g}$ creatine kinase, $5 \mathrm{~mm}$ creatine phosphate, $0.86 \mathrm{~mm}$ GTP, $0.36 \mathrm{~mm}$ ATP, $2.5 \mathrm{~mm}$ magnesium acetate, and $30 \mu \mathrm{m}$ hemin. After $1 \mathrm{hr}$ at $30^{\circ} \mathrm{C}$, the incubation mixture was chilled in ice-cold water and $4 \mathrm{M} \mathrm{KCl}$ was slowly added to give the final concentration of $0.35 \mathrm{M}$. The mixture was put on $30 \mathrm{ml}$ of a convex sucrose gradient ranging from 0.35 to $1.1 \mathrm{M}$ sucrose containing $20 \mathrm{~mm}$ Tris- $\mathrm{HCl}(\mathrm{pH} 7.4), 0.35 \mathrm{M} \mathrm{KCl}, 3.5 \mathrm{~mm}$ magnesium acetate, and $5 \mathrm{~mm}$ mercaptoethanol. The gradient was centrifuged at $24,000 \mathrm{rpm}$ in a Hitachi rotor RPS 25 for $22 \mathrm{hr}$ at $5^{\circ} \mathrm{C}$. After centrifugation, the gradient was pumped from the bottom of the centrifuge tube through an ISCO UV monitor, model UA-5. Fractions corresponding to the $40 \mathrm{~S}$ and $60 \mathrm{~S}$ peaks were collected according to the absorbance profile at $254 \mathrm{~nm}$. The subunits were collected by centrifugation at $30,000 \mathrm{rpm}$ for $22 \mathrm{hr}$ in a Hitachi rotor RP65 at $5^{\circ} \mathrm{C}$. Ribosomal pellets were suspended in ice-cold buffer $(20 \mathrm{~mm}$ Tris- $\mathrm{HCl}(\mathrm{pH}$ 7.4), $0.1 \mathrm{M} \mathrm{NH} \mathrm{NH}_{4} \mathrm{Cl}, 2 \mathrm{~mm}$ magnesium acetate, $1 \mathrm{~mm}$ mercaptoethanol) and used for the poly(U)-directed poly(Phe) synthesis.

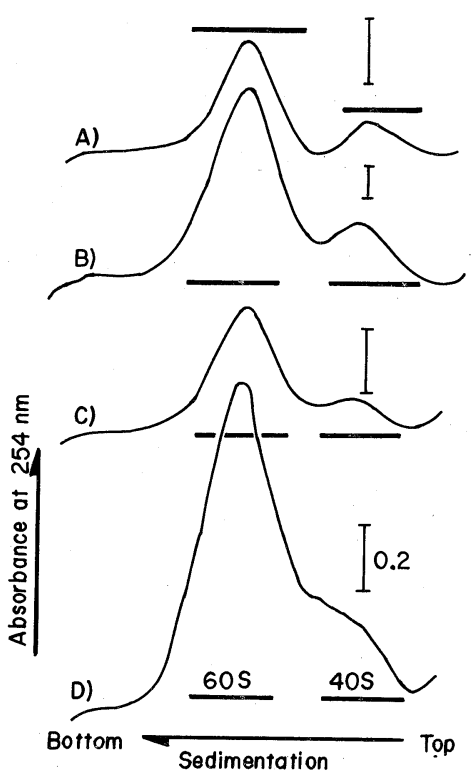

FIG. 1. Sedimentation profiles of control (A, C) and colicin E3-treated lysates (B, D). Portions of $0.55 \mathrm{ml}$ of lysate were preincubated for $1 \mathrm{hr}$ at $30^{\circ} \mathrm{C}$ with $0 \mu \mathrm{g}(\mathrm{A}, \mathrm{C})$, $62 \mu \mathrm{g}$ (B), and $130 \mu \mathrm{g}$ of colicin E3 (D) $/ \mathrm{A}_{260}$ unit of ribosomes in a final volume of $1 \mathrm{ml}$. The incubation mixture was centrifuged through the sucrose gradient and the gradient was fractionated from the bottom of the centrifuge tube. Fractions indicated by a bar were collected and used for the poly(U)-directed poly(Phe) synthesis as shown in Table I. The control incubations for profiles $\mathrm{B}$ and $\mathrm{D}$ are shown as profiles $\mathrm{A}$ and $\mathrm{C}$, respectively. A scale of absorbance at $254 \mathrm{~nm}$ per $1 \mathrm{~cm}$ path length is also shown (0.2). 
Table I. Activity of Hybrid Ribosomes Reconstituted from CONTROL and Colicin E3-Treated Ribosome Subunits

\begin{tabular}{|c|c|c|c|c|}
\hline \multicolumn{2}{|c|}{ Ribosome subunits } & \multicolumn{3}{|c|}{ Poly(Phe) synthesis } \\
\hline $40 \mathrm{~S}$ & $60 \mathrm{~S}$ & cpm (observed) & $\begin{array}{c}\mathrm{cpm} \\
\text { (correcte }\end{array}$ & $\begin{array}{c}\% \\
\text { S alone) }\end{array}$ \\
\hline \multicolumn{5}{|l|}{ Expt. 1} \\
\hline \multirow[t]{2}{*}{ Control } & & 171 & & \\
\hline & Control & 90 & & \\
\hline \multirow{2}{*}{ Colicin E3 } & & 23 & & \\
\hline & Colicin E3 & 105 & & \\
\hline Control & Control & 1287 & 1026 & 100 \\
\hline Colicin E3 & Colicin E3 & 935 & 807 & 79 \\
\hline Control & Colicin E3 & 971 & 695 & 68 \\
\hline Colicin E3 & Control & 1318 & 1205 & 117 \\
\hline \multicolumn{5}{|l|}{ Expt. 2} \\
\hline \multirow[t]{2}{*}{ Control } & & 108 & & \\
\hline & Control & 171 & & \\
\hline \multirow[t]{2}{*}{ Colicin E3 } & & 186 & & \\
\hline & Colicin E3 & 386 & & \\
\hline Control & Control & 2265 & 1986 & 100 \\
\hline Colicin E3 & Colicin E3 & 1420 & 848 & 43 \\
\hline Control & Colicin E3 & 1165 & 671 & 34 \\
\hline Colicin E3 & Control & 2614 & 2257 & 114 \\
\hline
\end{tabular}

Ribosomal subunits used were the preparations obtained by the experiments shown in Fig. 1. Expts. 1 and 2.were done using the ribosomal subunits obtained from the fractions shown in Fig. 1A, B and Fig. 1C, D, respectively. Amounts of ribosomal subunits $\left(A_{260}\right.$ unit) in each experiments: (Expt. 1), control 40S, 0.116; control 60S, 0.309; colicin E3-treated 40S, 0.117; colicin E3-treated 60S, 0.293. (Expt. 2), control 40S, 0.168; control 60S; 0.450; colicin E3treated 40S, 0.173; colicin E3-treated 60S, 0.480.

Poly(U)-directed poly(Phe) synthesis was measured in $100 \mu \mathrm{l}$ of incubation mixture containing $40 \mathrm{~mm}$ Tris- $\mathrm{HCl}$ (pH 7.4), 5 mm magnesium acetate, $0.86 \mathrm{~mm}$ GTP, $0.36 \mathrm{~mm}$ ATP, $5 \mu$ g creatine kinase, $5 \mathrm{~mm}$ creatine phosphate, $10 \mu \mathrm{l}$ of $\mathrm{pH} 5$ enzyme, $10 \mu \mathrm{l}$ of postribosomal supernatant of rabbit reticulocytes lysate, $0.13 A_{260}$ units of poly(U), $1.25 \mu \mathrm{Ci}\left[{ }^{3} \mathrm{H}\right] \mathrm{Phe}$, and various amounts of $40 \mathrm{~S}$ and $60 \mathrm{~S}$ ribosomal subunits. After $60 \mathrm{~min}$ at $30^{\circ} \mathrm{C}, 50 \mu \mathrm{l}$ of the incubation mixture was taken into $1 \mathrm{ml}$ of ice-cold water and $2 \mathrm{ml}$ of $9 \%$ trichloroacetic acid were added. After boiling for $20 \mathrm{~min}$, the mixture was kept in ice-cold water for $1 \mathrm{hr}$, the precipitates were collected, and the radioactivity was measured as described. ${ }^{2)}$

Control and colicin E3-treated ribosome subunits were prepared as described above and poly(U)-directed poly(Phe) synthesis was measured using these subunits. As Table I shows, hybrid $80 \mathrm{~S}$ ribosomes reconstituted from control $40 \mathrm{~S}$ and colicin E3-treated $60 \mathrm{~S}$ ribosome subunits had a lower activity to synthesize poly(Phe). This clearly shows that colicin E3 inactivated the $60 \mathrm{~S}$ ribosomal subunits of reticulocytes and explains why colicin E3 inhibited the formation of $80 \mathrm{~S}$ initiation complexes in a reticulocyte cell-free system. ${ }^{1)}$

The sedimentation profiles of colicin E3-treated lysates showed relatively high absorbances at fractions of $40 \mathrm{~S}$ and $60 \mathrm{~S}$ ribosome regions and at fractions between these subunits as compared with control lysates. Higher amounts of the ribosomal subunits are ascribable to the accumulation of $80 \mathrm{~S}$ ribosomes, since colicin E3 inhibits the initiation of globin synthesis. ${ }^{1)}$ From the absorbance profiles in Fig. 1, we roughly estimated the amounts of $40 \mathrm{~S}$ and $60 \mathrm{~S}$ ribosome subunits. The ratio of the amounts of $40 \mathrm{~S}$ to $60 \mathrm{~S}$ ribosome subunits was found to be decreased by the colicin E3-treatment of lysates. It is therefore conceivable that colicin E3 cleaves $60 \mathrm{~S}$ ribosome subunits to release fragments and the fragments bind with $40 \mathrm{~S}$ ribosome subunits to cause higher absorbance at fractions between $40 \mathrm{~S}$ and $60 \mathrm{~S}$ ribosome subunits (Fig. 1B, D).

Though Turnowsky et al. ${ }^{5)}$ reported that the binding of Met-tRNA to $_{\mathrm{f}}$ toS ribosomes was not inhibited by the colicin E3-treatment of ascites ribosomes, they reported the inactivation of ascites ribosomes with colicin E3 in experiments similar to those in Table I. Since colicin E3 inactivated $60 \mathrm{~S}$ ribosomal subunits from reticulocytes (Table I) and ascites cells, ${ }^{5}$ ) it must be general in mammalian ribosomes that colicin E3 inactivates $60 \mathrm{~S}$ ribosomal subunits. 


\section{REFERENCES}

1) H. Suzuki, FEBS Lett., 89, 121 (1978).

2) H. Suzuki and Y. Hayashi, FEBS Lett., 52, 258 (1975).

3) H. R. Herschman and D. R. Helinski, J. Biol. Chem.,
242, 5360 (1967).

4) A. K. Falvey and T. Staehelin, J. Mol. Biol., 53, 1 (1970).

5) F. Turnowsky, J. Drews, F. Eichi and G. Högenauer, Biochem. Biophys. Res. Commun., 52, 327 (1973). 